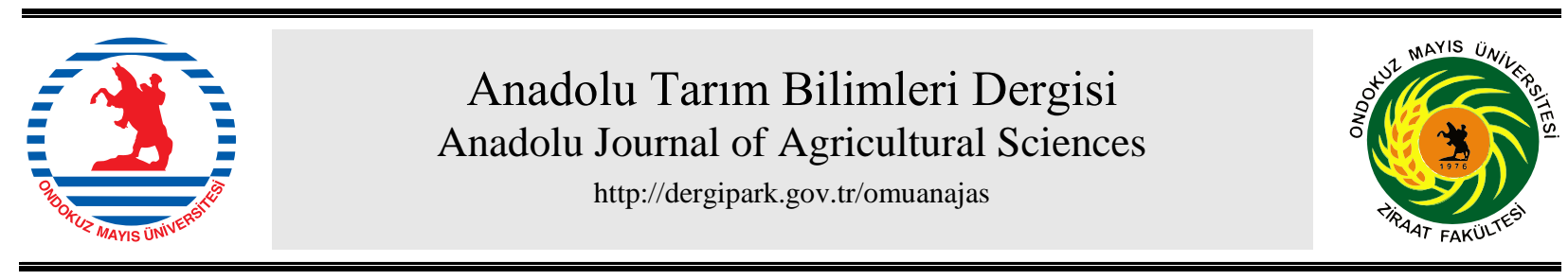

Research/Araştırma

Anadolu Tarım Bilim. Derg./Anadolu J Agr Sci, 32 (2017) ISSN: 1308-8750 (Print) 1308-8769 (Online) doi: 10.7161/omuanajas.289354

\title{
Evaluation of temperature distribution in different greenhouse models using computational fluid dynamics (CFD)
}

\author{
Bilal Cemek $^{\mathrm{a}^{*}}$, Aslıhan Atişs ${ }^{\mathrm{b}}$ Erdem Küçüktopcu ${ }^{\mathrm{a}}$ \\ ${ }^{a}$ Faculty of Agriculture, OndokuzMayis University, Samsun, Turkey \\ ${ }^{b}$ Black Sea Agricultural Research Institute, Samsun, Turkey \\ *Corresponding author/sorumlu yazar: bcemek@omu.edu.tr
}

Geliş/Received 22/04/2016 Kabul/Accepted 07/12/2016

\begin{abstract}
Areas of air inlet and outlet openings, orientation of openings, height difference between air inlet and outlet openings, wind direction, greenhouse geometry, and type of plant grown are among the many factors that should be taken into consideration in designing an effective ventilation system for greenhouses. In this study, five different model plastic greenhouses with different sidewall heights, air inlet and outlet opening areas and roof shapes were used to evaluate the ventilation efficiencies and they were compared with a conventional type of the region. A computational fluid dynamics (CFD) program was used to evaluate the behavior of the internal environment (internal flow rate and temperature distributions) and natural ventilation rates for all model greenhouses and a conventional greenhouse involved in the study. External wind speeds of $0.5,1$, and $2 \mathrm{~ms}^{-1}$ were used in the simulations for all conditions. The results of simulations and experimental studies were evaluated and used for recommendation of a better greenhouse model for this region. CFD software "FLUENT" was used to determine the effectiveness of greenhouse ventilation system and k- $\varepsilon$ Renormalization Group (RNG) turbulence model was used in solutions.
\end{abstract}

\section{Hesaplamalı akışkanlar dinamiği (HAD) kullanılarak farklı sera modellerindeki sıcaklık dağılımının değerlendirilmesi}

\section{ÖZET}

Hava giriş ve çıkış açıklıklarının alanları, konumları, giriş ve çıkış açıklıkları arası yükseklik farkı, rüzgar yönü, sera geometrisi ve serada yetiştirilen bitki çeşidi gibi birçok faktör havalandırma sisteminin planlanmasında etkili olmaktadır. Bu çalışmada havalandırma sistemlerinin etkisini değerlendirebilmek amacıyla farklı yan duvar yüksekliğine, havalandırma giriş çıkış açıklıklarına ve sera çatı şekillerine sahip beş farklı özellikte plastik sera kullanılmış ve bu sera modelleri ile bölgede kullanılan tipik sera modeli karşılaştırılmıştır. Çalışmada kullanılan tüm sera modellerinin iç çevre koşulları (hava akış hızı ve sıcaklık dağılımları) ve hava değişim oranları Hesaplamalı Akışkanlar Dinamiği (HAD) ile değerlendirilmiştir. Simülasyonlardaki tüm koşullar için dış hava hızı $0.5,1$ ve 2 $\mathrm{ms}^{-1}$ olarak belirlenmiştir. Sera içi etkili havalandırma sisteminin çözümünde HAD'nin "FLUENT" yazılım programından yararlanılmıştır. Çözümde ise türbülans modeli olarak k- $\varepsilon$ Renormalization Group (RNG) türbülans modeli kullanılmıştır.

Keywords: Computational fluid dynamics Natural ventilation, Greenhouse Samsun

\section{Introduction}

Greenhouses are complex facilities to provide an efficient plant production, growth and development year-around. Growth factors like light, temperature, humidity and air composition should be provided at optimum levels. Beside the Mediterranean coastal line, greenhouse facilities widespread in Eagan, Marmara, Blacksea and GAP regions of Turkey. However, the regions with lower heating costs are usually preferred for early vegetable and ornamental plant production. Considering the demands for early vegetable and ornamental plants and recently for early fruit production, climate, irrigation water and soil texture are the main factors to determine the suitability of a region for greenhouse business. Temperature, precipitation and solar radiation values are observed along the Mediterranean coastal line for greenhouses during the 
intensive greenhouse production periods between the months December-March. On the other hand, greenhouses of Blacksea region have an advantage over Mediterranean greenhouses during the spring and summer months since they don't need cooling during these months. This advantage brings significant gains for Blacksea greenhouse with regard to late production during spring months and early production during fall months (Cemek et al., 2015).

Natural ventilation systems can provide limited control over air movement inside a greenhouse. In this case, difficulties are experienced in controlling the greenhouse inside temperature, relative humidity and $\mathrm{CO}_{2}$ concentrations. Therefore, natural ventilation mechanism should be analyzed in deeper fashion to improve greenhouse ventilation efficiency and to better understand the dependency of ventilation rates on greenhouse constructional plans. Natural ventilation is performed by pressure gradient created either by wind or temperature difference between ventilation openings. Dominance of wind velocities over $2 \mathrm{~ms}^{-1}$ over ventilation processes was experimentally proved (Papadakis et al., 1994; Kittas et al., 1996). In this case, impact of air temperature gradient may be neglected. On the other hand, ventilation by temperature gradient is a significant issue in weak wind conditions $\left(\mathrm{V}_{\mathrm{w}}<0.5 \mathrm{~ms}\right.$ ${ }^{1}$ ).

Air flow created by temperature gradient between greenhouse inner air layers is defined with the term "chimney effect". Ventilation is mostly provided by the effect of wind in cases where wind speed is between $0.5-2.0 \mathrm{~ms}^{-1}$ and chimney effect is observed in this case. Computational Fluid Dynamics (CFD) s used to analyze air and heat flow in natural ventilation systems. In this way, better ventilation efficiencies may be achieved and the best greenhouse model can be developed for the region. Since inception design of ventilation studies, CFD simulations have been widely used as a power tool in different architectural and building structure engineering areas (IEA 1992).

CFD is especially used for analysis and performance test of fluid-related products. Fluid dynamics software allows the users to solve continuity, momentum and energy equations numerically by use of computers and get the distribution of desired flow-related parameters. Rapid developments and efficient analysis provided by CFD have made this topic a significant issue in technology development. It is hard to find expert personnel professionally dealing with this topic to solve fluid-related problems.

CFD technique can also be used as a powerful tool to develop constructional plans with efficient ventilation and to model the greenhouse inside climate conditions. Systematic mechanism should be well-defined for efficient control of greenhouse inside climate conditions and for better definition of ventilation system characteristics. The computational effort required can be large and is dependent on the number of computational cells in a domain, the number of variables solved in each cell and the kind of simulated transport processes (Patankar, 1980).

Investigation of structural characteristics of greenhouses with regard to ventilation efficiencies at different wind velocities may pave the way for greenhouse designers to provide more efficient ventilation through temperature gradient. CFD simulations were successfully used to estimate ventilation created by wind effect in greenhouses (Mistriotis et al., 1997). However, limited advancements were observed in cases with low wind velocities and in cases where ventilation is mostly implemented by temperature gradient. That was mostly due to lack of sufficient experimental data to prove the simulation results.

CFD is a simulation tool used to analyze flow processes of fluids, heat and mass transfers (Reichrath and Davies, 2002). Typical outputs of CFD simulations are temporal and spatial distributions of flow velocity, direction, pressure and heat concentrations. It is mostly used in chemistry, automotive industry, aviation sciences and nuclear technologies and recently used in food processing applications. CFD is also used in agricultural implementations, especially in modeling greenhouse inside climate conditions. These kinds of models are usually used to model inner conditions based on outer condition and control strategies.

\subsection{History of CFD in the greenhouses}

The first studies on CFD were theoretically based and began to gain momentum in the mid-1950s (Morris and Neale, 1954; Businger, 1954), followed by the experimental studies with passing on of time (Lawrence and Whittle, 1960; Okada and Takakura, 1973; Bot, 1983; Nederhoff et al., 1985; De Jong, 1989; Fernandez and Bailey, 1992).

Recently, low cost and reliability are considered (Sase et al., 1984; Okushima et al., 1989; Sevila et al., 1992; Boulard, 1993; Papadakis et al., 1994; Boulard and Baille, 1995; Boulard and Draoui, 1995).

Kacira and Sase (2004) evaluated the ventilation performance of a greenhouse by recording greenhouse inner and outer climate factors and compared the records with data obtained by using computational fluid dynamics to analyze and optimize natural ventilation system of the greenhouse.

Norton et al. (2002) stated that CFD could be preferred an effective tool for proper analysis of inner climate conditions of structures under different design conditions. Researchers also stated that number of physical tests could significantly be reduced by using computational fluid dynamics technology. CFD, as a simulation technique, can provide spatial and temporal solutions for fluid pressure, temperature and velocity. It is also used efficiently in system design and optimization of chemistry, aviation and hydrodynamic systems. Common utilizations are also observed in evaluation of fluid impacts on system performances of 
several other disciplines (IEA, 1992).

The aim of this study, that greenhouse developed in Samsun, to provide a more lucrative crop production in greenhouse, to determine of natural ventilation systems which provide optimal indoor environmental conditions affect growth and yield of plant. Firstly, greenhouse models with five different ventilation heights were created. This models were applied to the three different $\left(0.5,1,2 \mathrm{~ms}^{-1}\right)$ wind speed and these applications were examined in two different months (May and June). Lastly temperature distribution was researched at the greenhouse inside.

\section{Material and Methods}

\subsection{Greenhouse characteristics}

Research site is located at latitude $41^{\circ} 17^{\prime}$ and longitude $36^{\circ} 18^{\prime}$ 'Samsun Province of Turkey. Climatic data is presented in Table 1 as the average of years between 1975-2009.

Table 1. Climate data of Samsun (1975-2009)

\begin{tabular}{lcccccccccccc}
\hline $\begin{array}{l}\text { Meteorological } \\
\text { Elements }\end{array}$ & Jan. & Feb. & Mar. & Apr. & May & June & July & Aug. & Sep. & Oct. & Nov. & Dec. \\
\hline $\begin{array}{l}\text { Avg. Temp. } \\
\left({ }^{\circ} \mathrm{C}\right)\end{array}$ & 7.01 & 6.64 & 8.00 & 11.20 & 15.40 & 20.14 & 23.27 & 23.59 & 20.00 & 16.00 & 11.84 & 8.86 \\
$\begin{array}{l}\text { Avg. Humidity } \\
(\%)\end{array}$ & 67.40 & 69.50 & 75.00 & 79.00 & 80.20 & 75.97 & 74.04 & 73.50 & 75.50 & 76.20 & 69.95 & 65.85 \\
$\begin{array}{l}\text { Avg. Wind } \\
\left.\text { speed (ms }{ }^{-1}\right)\end{array}$ & 3.30 & 2.90 & 2.40 & 1.95 & 1.67 & 1.97 & 2.35 & 2.34 & 2.15 & 2.12 & 2.47 & 3.17 \\
$\begin{array}{l}\text { Global radiation } \\
\left(\mathrm{kwhm}^{-2} \mathrm{~d}^{-1}\right)\end{array}$ & 1.57 & 2.20 & 3.10 & 4.06 & 5.13 & 5.97 & 5.96 & 5.22 & 4.02 & 2.64 & 1.78 & 1.37 \\
\hline
\end{tabular}

Comparison of Samsun greenhouses' air conditioning demands according to daily temperature and radiance values is presented in Figure 1. Mechanical cooling systems are not required in Samsun since the threshold values for natural ventilation are 12$22{ }^{\circ} \mathrm{C}$. The amount of greenhouse air to be changed in an hour is called "Air Exchange Rate". A recommended AER is between 30-40.
However, Von Zabeltitz (2011) indicates that air exchange rate should be 0.6- 2 for greenhouses with closed windows, 20-40 for poorly ventilated greenhouses, 40-50 for well-ventilated greenhouses and over 50 for very-well ventilated greenhouses. In this study, air change rate was taken as 60 per hour, therefore 1 per minute (Table 2).

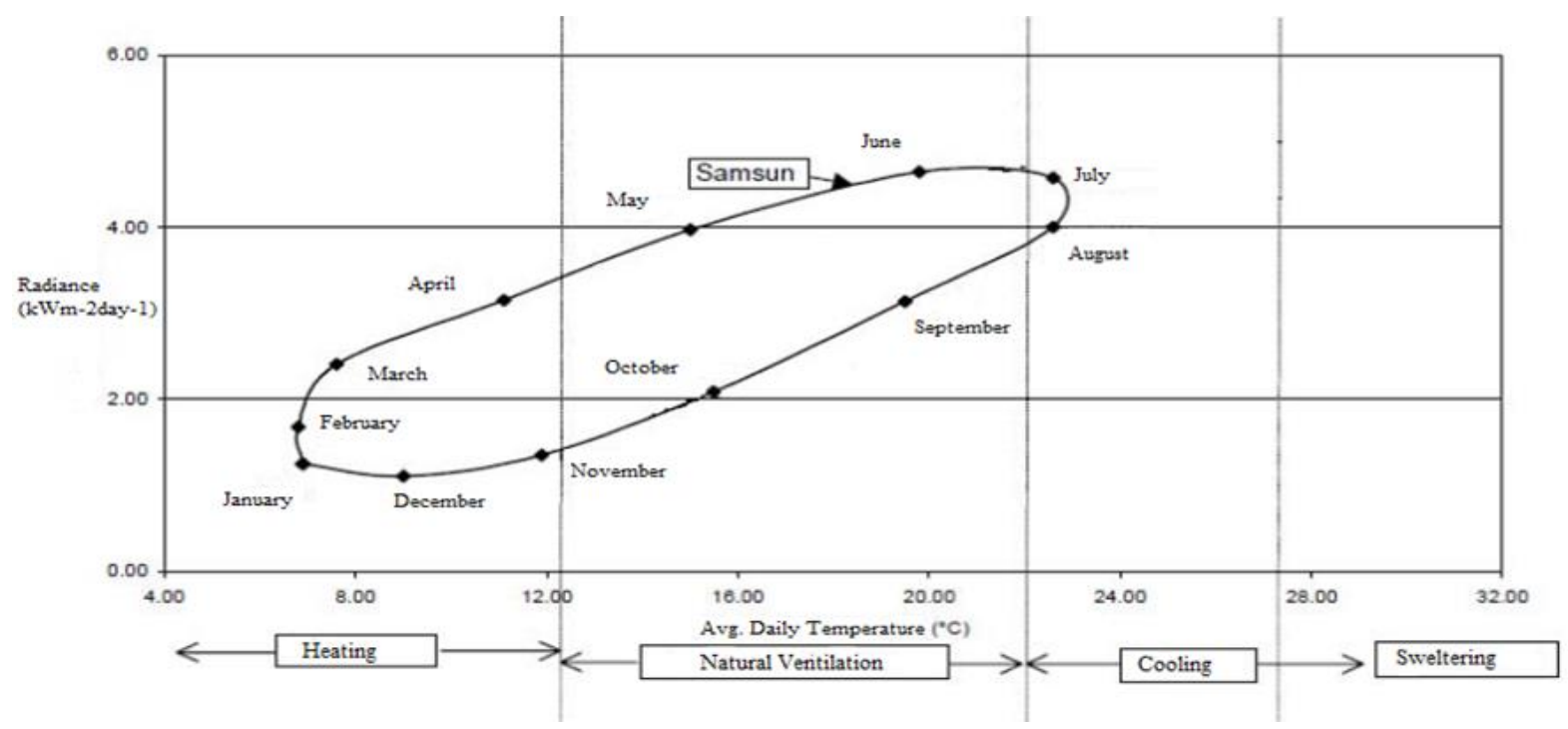

Figure 1. Comparison of air-conditioning demands according to daily temperature and radiance values of Samsun at greenhouses 
Table 2. Characteristics of climate conditions for ventilation months used in ANSYS 12.1 of CFD application

\begin{tabular}{ccc}
\hline & May & June \\
\hline Soil Temperature $\left({ }^{\circ} \mathrm{C}\right)$ & 21.00 & 27.00 \\
Cover Temperature $\left({ }^{\circ} \mathrm{C}\right)$ & 20.00 & 25.00 \\
Temperature of greenhouse inside $\left({ }^{\circ} \mathrm{C}\right)$ & 21.20 & 26.10 \\
Temperature of greenhouse outside $\left({ }^{\circ} \mathrm{C}\right)$ & 15.30 & 20.10 \\
Wind Direction & From west to east & From west to east \\
Wind Speed $\left(\mathrm{ms}^{-1}\right)$ & $0.5,1,2$ & $0.5,1,2$ \\
\hline
\end{tabular}

Table 3. Structural properties of five different models

\begin{tabular}{ccccccc}
\hline Greenhouse & $\begin{array}{c}\text { Height of } \\
\text { side wall }\end{array}$ & $\begin{array}{c}\text { Height of } \\
\text { ridge }\end{array}$ & $\begin{array}{c}\text { Ventilation } \\
\text { space of side } \\
\text { wall }\end{array}$ & $\begin{array}{c}\text { Ventilation } \\
\text { space of roof }\end{array}$ & $\begin{array}{c}\text { Height of } \\
\text { effective } \\
\text { ventilation }\end{array}$ & $\begin{array}{c}\text { Floor field of } \\
\text { greenhouse }\end{array}$ \\
\hline 1 & 200 & 400 & 20 & 20 & 300 & 120 \\
2 & 250 & 450 & 20 & 20 & 350 & 120 \\
3 & 300 & 500 & 20 & 20 & 400 & 120 \\
4 & 300 & 500 & - & 20 & - & 120 \\
5 & 300 & 500 & 20 & - & - & 120 \\
\hline
\end{tabular}

According to Bot (1983), type of window, opening angle, wind speed, wind direction and temperature difference were affected natural ventilation. In this study, 5 different greenhouse models were used.

Characteristics of these greenhouses were presented in Table 3. Side-wall air inlet openings should either be equal to ridge ventilation openings or at least $1 / 2-2 / 3$ of these openings (Anonymous, 2008).

\subsection{Methods used to determine the environmental conditions of greenhouses}

Ventilation requirements of a greenhouse is calculated by using the heat-balance relationships (Von Zabeltitz, 2011). Heat gains of a greenhouse are composed of solar radiation, equipment inside greenhouse, heating system and heat released by plants during respiration. Heat loses are composed of conductive heat loss from greenhouse base an surfaces contact with outer atmosphere, radiative heat loss from greenhouse atmosphere, infiltrative heat loss from uncontrolled openings, and the heat loss due to ventilation and photosynthesis. Among these heat loses, the ones from respiration, photosynthesis and base of greenhouse can be neglected. The heat generated by equipment should be considered in heating system and heat loss by radiation should be considered in conductive heat loss (Hellickson and Walker, 1983; Anonymous, 2008). Heat balance equation can be expresses as follows;

$$
(1-E) \tau I A_{f}=U A_{c}\left(t_{i}-t_{o}\right)+\frac{M}{v} c_{p}\left(t_{i}-t_{o}\right)+0.5 V_{s} N\left(t_{i}-t_{o}\right)
$$

where; E, Ratio of evapotranspiration to solar radiation; F, plant cover coefficient; $\tau$, light transmission of cover material (\%); I, solar radiation intensity $\left(\mathrm{kWm}^{-2}\right) ; \mathrm{A}_{\mathrm{f}}$, greenhouse floor area $\left(\mathrm{m}^{2}\right)$; $\mathrm{U}$, heat transmission coefficient of greenhouse surfaces $\left(\mathrm{Wm}^{-}\right.$ $\left.{ }^{2}{ }^{\circ} \mathrm{C}^{-1}\right) ; \mathrm{A}_{\mathrm{c}}$, greenhouse covers area $\left(\mathrm{m}^{2}\right) ; \mathrm{M}$, ventilation capacity $\left(\mathrm{m}^{3} \mathrm{~kg}^{-1}\right) ; \mathrm{v}$, specific volume of air $\left(\mathrm{m}^{3} \mathrm{~kg}^{-1}\right) ; \mathrm{c}_{\mathrm{p}}$, specific heat of air $\left(\mathrm{kJ} \mathrm{kg}^{-1}{ }^{\circ} \mathrm{C}^{-1} ; \mathrm{c}_{\mathrm{p}}=1 \mathrm{kjkg}^{-1}{ }^{\circ} \mathrm{C}^{-1}\right) ; \mathrm{t}_{\mathrm{i}}$, greenhouse inner temperature $\left({ }^{\circ} \mathrm{C}\right) ; \mathrm{t}_{\mathrm{o}}$, outer design temperature $\left({ }^{\circ} \mathrm{C}\right) ; \mathrm{V}_{\mathrm{s}}$, volume of greenhouse $\left(\mathrm{m}^{3}\right) ; \mathrm{N}$, air change coefficient $\left(1 \mathrm{~h}^{-1}\right)$.

\subsection{Equations used in computational fluid dynamics solutions}

In this study, ANSYS 12.1 software was used to solve the models. Geometries of 6 different greenhouse models were defined and relevant meshes were created with this software. Then, the models were solved by using FLUENT program of ANSYS 12.1 software and results were obtained from this section. The FLUENT uses Navier Stokes equations. Some of these equations are like the one given above. Equations can be written in a general form as given below to provide an easier solution in Fluent program (Launder and Spalding, 1974).

$$
\frac{\partial \varphi}{\partial t}+\vec{\nabla} \cdot \varphi \cdot \vec{V}=\vec{\nabla} \cdot\left(\Gamma_{\varphi} \cdot \vec{\nabla}_{\varphi}\right)+S \varphi
$$

where $\vec{V}$ Velocity vector $\quad\left(\mathrm{ms}^{-1}\right) ; \Gamma_{\psi}$, flow diffusion 
constant; $\mathrm{S}_{\psi}$, body forces; $\psi$, flow constant. Input flow is assumed to be unpressurized due to low logarithmic velocity acceleration.

$$
\begin{aligned}
& U_{i n l}(z)=\frac{u_{*}}{k} \ln \left(\frac{z+z_{0}}{z_{0}}\right) \\
& u_{*}=\frac{\kappa \cdot U_{h}}{\ln \left(\left(h+z_{0}\right) / z_{0}\right)}
\end{aligned}
$$

where; $\mathrm{U}_{\text {inl }}$, input velocity $\left(\mathrm{ms}^{-1}\right) ; \mathrm{u}_{*}$, frictional velocity $\left(\mathrm{ms}^{-1}\right) ; \kappa$, Von-Karman constant $(\kappa=0.42)$; z, fluid effective height $(\mathrm{m}) ; \mathrm{Z}_{0}$, length of friction along the flow (m); $\mathrm{U}_{h}$, reference velocity $\left(\mathrm{ms}^{-1}\right)$; $\mathrm{h}$, reference height $(\mathrm{m})$.

\subsection{Model solution stages}

\subsubsection{Geometry definition}

Greenhouse height is an important factor for ventilation. Studies relating to this parameter are quite limited. According to Boulard et al. (2004) increase of greenhouse height causes a decrease in greenhouse temperature.

The subject of the first known published work in this area was an empty single span pitched roof greenhouse with side vents and roof vents. Taking a cue from the above, Geometry of greenhouses were designed as empty geometry in this study. Side and roof of greenhouses vent opening angles stably were used as $45^{\circ}$ and $60^{\circ}$ respectively. Ventilation configurations used for simulations were as follows;

Configuration 1, roof and side vent openings are open, Chimney effect is $3 \mathrm{~m}$

Configuration 2, roof and side vent openings are open, Chimney effect is $3.5 \mathrm{~m}$

Configuration 3, roof and side vent openings are open, Chimney effect is $4 \mathrm{~m}$

Configuration 4 , only roof vent openings are open

- Configuration 5, only roof vent openings

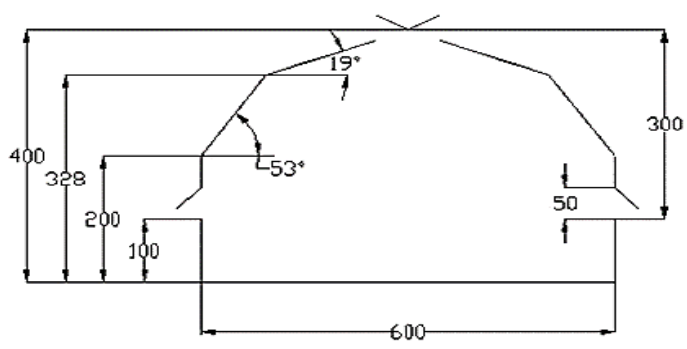

(a)

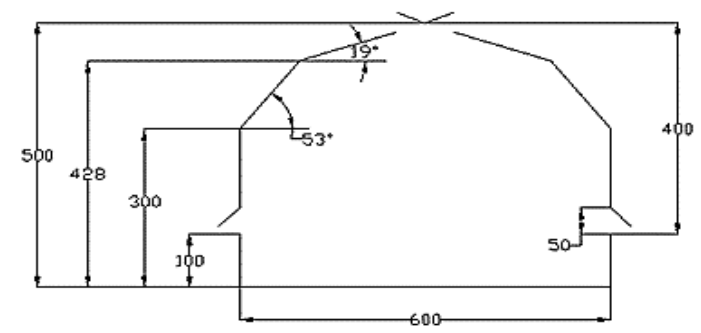

(c)

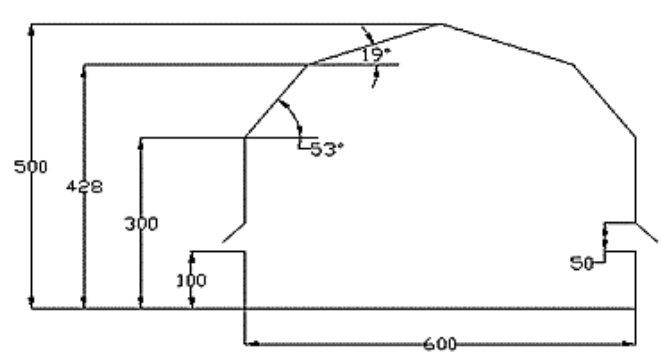

(e)

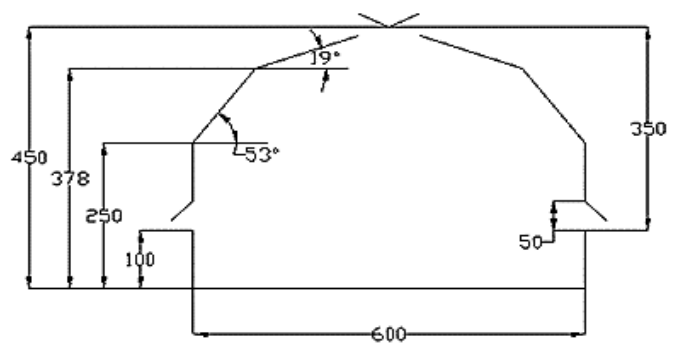

(b)



(d)

Figure 2. Schematic view of the five different configuration greenhouses 
ANSYS 12.1 software is used for geometry definition, mesh creation and model solutions. Model geometries were defined at $1 / 1$ scale as shown in Figure 2 . The critical point here is to perform naming of geometry before the definition of boundary conditions. Therefore, window opening for air flow inside the greenhouse was named as input, the opening for air flow outside the greenhouse was named as output and the other solid sections were named as wall. The program automatically assigns boundary condition types to these three types of elements. Boundary type of input surfaces was expressed by "velocity inlet", boundary type of output surfaces was expresses by "pressure outlet" and boundary type of wall surfaces was expressed by "wall". Greenhouse models were created by using above defined boundary conditions.

\subsubsection{Mesh creation}

A mesh should be created for better and accurate results. Therefore, flow space was divided into grid network called mesh. The more accurate the mesh creation, the better the solution will be. Fine grids should be defined at air inlet and outlet sections for a more accurate solution.

Special methods of ANSYS 12.1 were used to create these fine grids. "Tetrahedron" mesh creation was used in this study to get the best mesh for greenhouse models.

\subsubsection{Solution with Fluent}

Choosing that right turbulence model is important in CFD studies. Turbulence models often used for greenhouses are the standard k-e model, the realizable k-e model, the Renormalization Group (RNG) model, the Chen and Kim (1987) model and the Reynold Stress Model (RSM). According to Reichrath and Davies (2002), RNG model gave better results than other models. Mistriotis et al. (1997) recommended CK and RNG models for their study. Nebbali et al. (2012) compared three different models and they proposed standard k- $\varepsilon$ model as ideal in the results of their study.

Following the proper mesh creation stage, greenhouse models were solved in Fluent. Technical solutions used at this stage were provided in Table 4. In this study RNG model was used as a turbulence model.

Table 4. Constants used in fluent solve and numerical parameters

\begin{tabular}{|c|c|c|}
\hline Solve & $\begin{array}{c}\text { Type } \\
\text { Velocity Formulation } \\
\text { Time } \\
\end{array}$ & $\begin{array}{l}\text { Pressure Based } \\
\text { Absolute } \\
\text { Steady } \\
\end{array}$ \\
\hline Model & $\begin{array}{l}\text { Energy } \\
\text { Viscous }\end{array}$ & $\begin{array}{c}\text { On } \\
\text { RNG k-e, Standard Wall Functions }\end{array}$ \\
\hline Material & Air & $\begin{array}{c}\text { Density }=1.225 \mathrm{kgm}^{-3}, \mathrm{cp}=1006.43 \mathrm{jkg}^{-1} \mathrm{~K}^{-1}, \\
\text { Thermal Conductivity }=0.0242 \mathrm{wm}^{-1} \mathrm{~K}^{-1}\end{array}$ \\
\hline Boundary Conditions & $\begin{array}{l}\text { Inlet } \\
\text { Outlet } \\
\text { Wall }\end{array}$ & $\begin{array}{l}\text { Velocity inlet } \\
\text { Pressure outlet } \\
\text { Wall }\end{array}$ \\
\hline Solution Methods & $\begin{array}{c}\text { Gradient } \\
\text { Pressure } \\
\text { Momentum } \\
\text { Turbulent Kinetic Energy } \\
\text { Turbulent Dissipation Rate } \\
\text { Energy } \\
\end{array}$ & $\begin{array}{l}\text { Least Squares Cell Based } \\
\text { Second Order } \\
\text { Second Order Upwind } \\
\text { Second Order Upwind } \\
\text { Second Order Upwind } \\
\text { Second Order Upwind } \\
\end{array}$ \\
\hline Solution Control & $\begin{array}{l}\text { Momentum } \\
\text { Turbulent Kinetic Energy } \\
\text { Turbulent Dissipation Rate } \\
\text { Turbulent Viscosity Energy }\end{array}$ & $\begin{array}{l}0.7 \\
0.8 \\
0.8 \\
1.0\end{array}$ \\
\hline
\end{tabular}


Among the turbulence models, RNG k- $\varepsilon$ model was generated differently from standard $\mathrm{k}$-model by using a statistical technique called "re-normalization group" method. Although model equations look similar to the ones used in Standard k-model, statistical derivations yielded different outcomes since different coefficients were used in equations.

Turbulence is generally affected by cyclone or vortex of flow. Fluent CFD code took cyclone or vortex of flow into consideration in calculations and developed RNG k- $\varepsilon$ turbulence model allowing proper turbulence viscosity calculation. Several researchers also compared

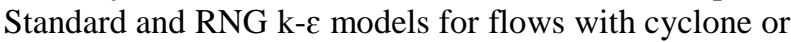
vortex effect and observed that RNG $\mathrm{k}-\varepsilon$ yielded more reliable compliances with experimental results and Standard k- $\varepsilon$ models were found to be insufficient.

Research on turbulent flows revealed that RNG k- $\varepsilon$ model yielded more reliable results than Standard k- $\varepsilon$ model for vortex flows, separated flows, static flows and curved geometries. Therefore, RNG k- $\varepsilon$ model was selected as turbulence model in this study. Constants for RNG k- $\varepsilon$ are provided in Table 5 (Abel and Monteiro, 2007).

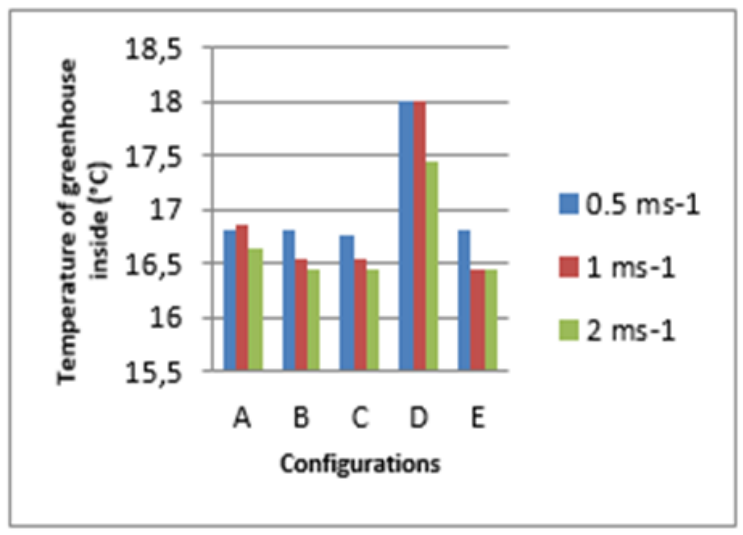

(a)
Table 5. Constants of RNG k- $\varepsilon$ model

$\begin{array}{lc}\mathrm{C} \mu & 0.0845 \\ \mathrm{C} 1 \varepsilon & 1.42 \\ \mathrm{C} 2 \varepsilon & 1.68 \\ \text { number } & 0.85\end{array}$

\section{Results and Discussion}

Natural ventilation is mainly performed by air flow from bottom to top through pressure gradient formed based on temperature difference between inner and outer temperature and relative humidity of air inside greenhouse, the highest elevation difference between air inlet and outlet openings, total area of air inlet and outlet openings and wind velocity. As a result of simulation operation, the temperature change occurs at greenhouses demonstrated differences. We compared five different ventilation height thus three different wind speed $\left(0.5,1,2 \mathrm{~ms}^{-1}\right)$ and these applications were examined in two different months (May and June). Due to different wind speeds, the temperature distributions in each greenhouse are given in Figure 3.



(b)

Figure 3. Temperature distribution of configurations at different wind speed on May (a) and June (b)

Air temperature taken from different points in the greenhouse (side wall vents openings, the center of the greenhouse, roof vents openings, etc.) shows variations. When both vents are opened, the internal airflow characterized $\mathrm{C}$ model by a strong air current located near the roof slopes (Table 6). A much weaker air circulation developed close to spans of other models. The simulations also indicate that the external air flow passes directly through both roof openings of $\mathrm{C}$ model and other models with an air temperature lower than the external wind temperature near both the roof and the floor Figure 4 and 5 present the temperature distribution for the same configuration.

It shows that the convective cells that develop on each span are fed both by cold air infiltrations coming through the vent openings and by buoyancy forces induced by thermal heat exchange with the hot walls of the greenhouse. Yet, due to the strong outside air penetration in the region located above of $\mathrm{C}$ model, the temperature is only $+1.5^{\circ} \mathrm{C}$ more than outside, whereas it increases up to $+2.0^{\circ} \mathrm{C}$ in the other models.

Table 6. Comparison of the temperatures in each configurations

\begin{tabular}{lll}
\hline & May & June \\
\hline Configuration 1 (A) & 0.57 & 0.57 \\
Configuration 2 (B) & 0.79 & 0.75 \\
Configuration 3 (C) & $\mathbf{0 . 8 9}$ & $\mathbf{0 . 8 8}$ \\
Configuration 4 (D) & 0.89 & 0.75 \\
Configuration 5 (E) & 0.57 & 0.57 \\
\hline
\end{tabular}


In model $\mathrm{A}$ at $0.5 \mathrm{~m} \mathrm{~s}^{-1}$ wind velocity, with the air temperature at air inlet on greenhouse side wall was $20.30{ }^{\circ} \mathrm{C}$, temperature was recorded as $26.10^{\circ} \mathrm{C}$ at side wall air outlet and as again $20.30{ }^{\circ} \mathrm{C}$ at center of the greenhouse. The temperature values in model $\mathrm{B}$ were $21.80{ }^{\circ} \mathrm{C}$ at $1 \mathrm{~m}$ elevation, $21.60{ }^{\circ} \mathrm{C}$ at $2 \mathrm{~m}$ and decreased to $21.50{ }^{\circ} \mathrm{C}$ at ridge ventilation. While the air temperature at air inlet on greenhouse side wall of model $\mathrm{C}$ was $21.80{ }^{\circ} \mathrm{C}$, it was recorded as $21.70{ }^{\circ} \mathrm{C}$ at side wall air outlet and center of the greenhouse. In model D, higher inner temperatures were observed than the others and these values were $23.90{ }^{\circ} \mathrm{C}$ at air inlet on greenhouse side wall and $23.70{ }^{\circ} \mathrm{C}$ at side wall air outlet and center of the greenhouse. The temperatures in model $\mathrm{E}$ at air inlet on greenhouse side wall, side wall air outlet and mid-section of the greenhouse varied between $21.60{ }^{\circ} \mathrm{C}$ and $22.10{ }^{\circ} \mathrm{C}$. The temperature values in model $\mathrm{F}$ were $21.70^{\circ} \mathrm{C}$ at $1 \mathrm{~m}$ elevation, 21.60 ${ }^{\circ} \mathrm{C}$ at $2 \mathrm{~m}$ and decreased to $21.50{ }^{\circ} \mathrm{C}$ at ridge ventilation. Greenhouse inner temperatures at $1 \mathrm{~ms}^{-1}$ wind velocity in model A varied between $26.10{ }^{\circ} \mathrm{C}$ and $20.20{ }^{\circ} \mathrm{C}$. Greenhouse mid-section temperature in model B was $21.40{ }^{\circ} \mathrm{C}$ at $1 \mathrm{~m}, 21.30{ }^{\circ} \mathrm{C}$ at $2 \mathrm{~m}$ and decreased to 21.20 ${ }^{\circ} \mathrm{C}$ at ridge ventilation. Air temperature at air inlet on greenhouse side wall of model $\mathrm{C}$ was $21.50{ }^{\circ} \mathrm{C}$, it was recorded as $21.40{ }^{\circ} \mathrm{C}$ at side wall air outlet and mid- section of the greenhouse. In model $\mathrm{D}$, while the temperature was $22.50{ }^{\circ} \mathrm{C}$ at air inlet on greenhouse side wall, it was $22.20^{\circ} \mathrm{C}$ at side wall air outlet and midsection of the greenhouse. Temperature was recorded as $21.30{ }^{\circ} \mathrm{C}$ at sidewall inlet, mid-section and sidewall outlet of model $\mathrm{E}$. The temperature values in model $\mathrm{F}$ were $21.40{ }^{\circ} \mathrm{C}$ at $1 \mathrm{~m}$ elevation, $21.20{ }^{\circ} \mathrm{C}$ at $2 \mathrm{~m}$ and decreased to $21.10{ }^{\circ} \mathrm{C}$ at ridge ventilation. Similar variations in inside temperatures of the five different models at $2 \mathrm{~ms}^{-1}$ wind velocity. Inner temperatures in model A varied between $22.10{ }^{\circ} \mathrm{C}$ and $20.20{ }^{\circ} \mathrm{C}$. Greenhouse mid-section temperature of model B was $19.20{ }^{\circ} \mathrm{C}$ at $1 \mathrm{~m}$ height $21.20^{\circ} \mathrm{C}$ at $2 \mathrm{~m}$ and $21.20^{\circ} \mathrm{C}$ at ridge ventilation. Air temperature at air inlet on greenhouse side wall of model $\mathrm{C}$ was $21.30^{\circ} \mathrm{C}$, it was recorded as $21.20^{\circ} \mathrm{C}$ at mid-section of the greenhouse and decreased to $21.00{ }^{\circ} \mathrm{C}$ at side wall air outlet. In model $\mathrm{D}$, while the temperature was $22.70{ }^{\circ} \mathrm{C}$ at air inlet on greenhouse side wall, it decreased to $22.60{ }^{\circ} \mathrm{C}$ at mid-section of the greenhouse and side wall air outlet. Temperature was recorded as $21.20^{\circ} \mathrm{C}$ at sidewall inlet, mid-section and sidewall outlet of model E. While the temperature value in model $\mathrm{F}$ was $21.20{ }^{\circ} \mathrm{C}$ at $1 \mathrm{~m}$ elevation of greenhouse mid-section, it was recorded as $21.00{ }^{\circ} \mathrm{C}$ at ridge ventilation (Figure 4 and 5).



(a)

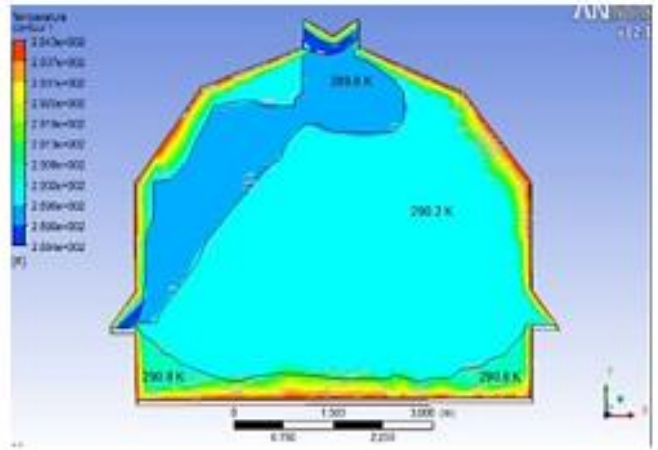

(b)

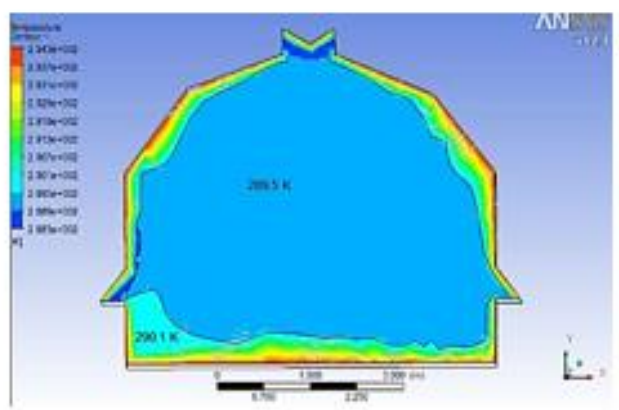

(c)

Figure 4. Temperature distribution of C configuration on May (a: $0.5 \mathrm{~ms}^{-1}$, b: $1 \mathrm{~ms}^{-1}, \mathrm{c}: 2 \mathrm{~ms}^{-1}$ wind speed) 


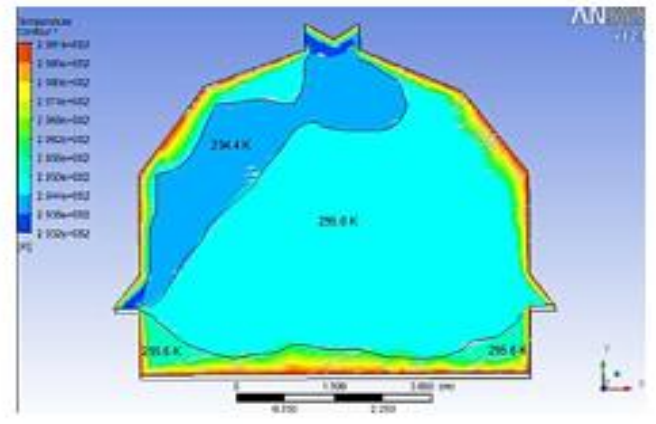

(a)

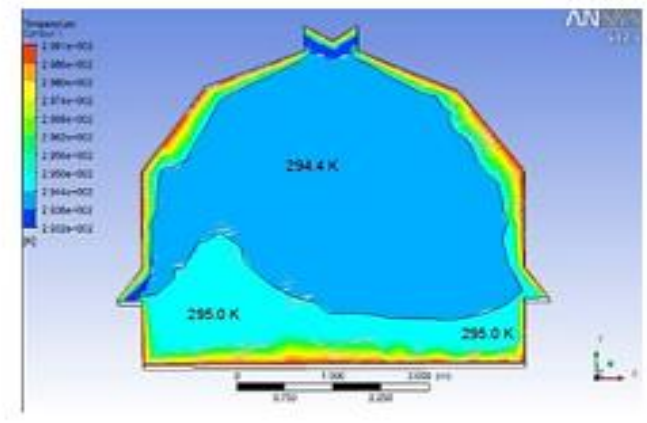

(b)

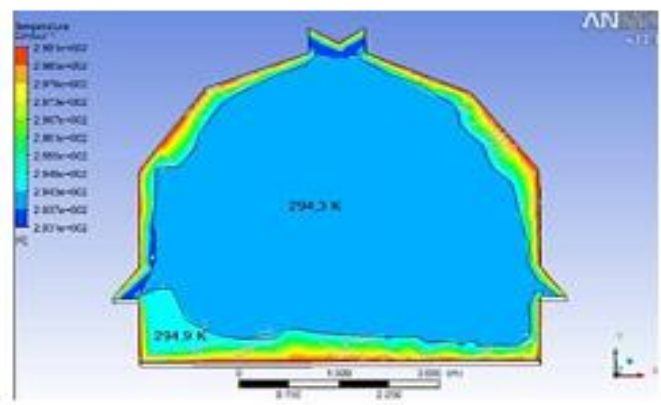

(c)

Figure 5. Temperature distribution of C configuration on June (a: $0.5 \mathrm{~ms}^{-1}, \mathrm{~b}: 1 \mathrm{~ms}^{-1}, \mathrm{c}: 2 \mathrm{~ms}^{-1}$ wind speed)

Results revealed that natural ventilation designs of models $\mathrm{A}, \mathrm{B}$, and $\mathrm{C}$ were similar to each other and effective ventilation height increases from $\mathrm{A}$ to $\mathrm{C}$. While inside temperatures of model A had lower values at sidewall air inlet and ridge ventilation, these values decreased more in model C. Since model $\mathrm{C}$ has 0.5 and $1 \mathrm{~m}$ higher effective ventilation height respectively than model A and B, better ventilation was observed in model C. Since model D did not have sidewall air openings, greenhouse inside temperature was higher and inside wind velocity was lower than that of the others. Lower variations in temperatures calculated by using climate data of the natural ventilation months indicated that Model D had lower ventilation efficiency than the other models and this model could not be recommended for this region. Model E which had air openings at only sidewalls and CFD results revealed the negative outcomes of lack of ridge ventilation openings in Samsun Province. For model F, different variations were observed in greenhouse inside climate parameters during the ventilation months. Since this model had the lowest effective ventilation height, an increase in greenhouse inside temperatures and a decrease in wind velocities were observed in this model.

\section{Conclusion}

The biggest problem of greenhouse growers is underutilized roof ventilation systems of greenhouses in
Samsun. Therefore, growers are faced with fungal diseases, decline in product quantity and quality in greenhouse. As Most of the greenhouses are the arc type roof it is difficult to form the roof ventilation system hence there are no ventilation system at roofs. Ventilation is provided with openings on the side walls and thus poor ventilation in the greenhouse. In order to ensure ideal growth of crops in greenhouses, adequate air exchange should be guaranteed. This requires a change of at least once per minute of the total volume of greenhouse.

This study considered the aerodynamics of natural ventilated greenhouse model used in the region and determined air exchange rate of six different greenhouse models which appropriate greenhouse cultivation. The results of this study recommended model $\mathrm{C}$, the model with the highest roof height than other models and with roof and side walls openings for the Samsun.

\section{Acknowledgments}

This study was supported by Ondokuz Mayis University, Scientific Research Programs under the project no PYO.ZRT.1904.10.30.

\section{References}

Abel, R., Monteiro, E., 2007. Computational fluid dynamics analysis of greenhouse microclimates by heated 
underground tubes. Journal of Mechanical Science and Technology. 21: 2196-2204.

Anonymous, 2008. Heating Ventilating and Cooling Greenhouses. American Society of Agricultural and Biological Engineers Standards, ASABE.

Bot, GPA., 1983. Greenhouse climate: from physical processes to dynamic model. PhD Dissertation, Agricultural University of Wageningen, Netherland.

Boulard, T., 1993. Etude experimentale et modélisation de 1' aération naturelle des serres (experimetal study and modelling of greenhouse natural ventilation). Récapitulation des résultats des études conduites de 1988 B 1992. Note Interne I.N.R.A. 93-1; Station de Bioclimatologie de Montfavet 84140 France. (in French).

Boulard, T., Baille, A., 1995. Modelling of Air Exchange Rate in a Greenhouse Equipped with Continuous Roof Vents. Journal of Agricultural Engineering Research, 61 (1):3747.

Boulard, T., Draoui, B., 1995. Natural ventilation of ventilation of a greenhouse with continuous roof vents: measurements and data analysis. Journal of Agricultural Engineering Research, 61:27-35.

Boulard, T., Fatnassi, H., Roy, JC., Lagier, J., Fargues, J., Smits, N., Rougier, M., Jeannequin, B., 2004. Effect of greenhouse ventilation on humidity of inside air and in leaf boundary-layer. Agricultural and Forest Meteorology, 125 (3-4): 225-239.

Businger, J.A., 1954. De invloed van raamstanden op de ventilatie in kassen. (The influence of window openings on the ventilation of greenhouse) Meded. Dir. Tuinbouw (Netherlands.). 17: 897 (in Dutch).

Cemek, B., Güler, M., Arslan, H., 2015. Spatial analysis of climate factors used to determine suitability of greenhouse production in Turkey. Theoretical and Applied Climatology, doi:10.1007/s00704-015-1686-5

Chen, Y.S., Kim, S.W., 1987. Computation of turbulent flows using an extended k- $\varepsilon$ model. NASA Contractor Report. NASA-Marshall Space Flight Center Marshall Space Flight Center, Alabama.

De Jong, T., 1989. Natural ventilation of long multi-span greenhouses. Ph.D. thesis, Agricultural University of Wageningen. Wageningen, Nederland.

Fernandez, J.E., Bailey, B.J., 1992. Measurements and prediction of greenhouse ventilation rates. Agricultural and Forest Meteorology, 58 (3-4): 229-245.

Hellickson, M.A., Walker, J.N., 1983. Ventilation of agricultural structures. American Society of Agricultural Engineers, Michigan. pp.257-300.

IEA, 1992. Energy conservation in building sand community systems programme. Annex 20: Air flow patterns within buildings. Air flow through large openings on buildings. Technical report edited by J. Van der Maas.

Kacira, M., Sase, S., 2004. Optimization of vent configuration by evaluating greenhouse and plant canopy ventilation rates under wind induced ventilation. Transactions of the ASAE, 47(6): 2059-2067.

Kittas, C., Boulard, T., Mermier, M., Papadakis, G., 1996. Wind-Induced Air Exchange-Rates in A Greenhouse Tunnel with Continuous Side Openings. Journal of Agricultural Engineering Research, 65(1):37-49.

Launder, B.E., Spalding, D.B., 1974. The numerical computation of turbulent flows. Computer Methods in Applied Mechanics and Engineering, 3(2): 269-289.

Lawrence, W.J.C., Whittle, R.M., 1960. The climatology of glasshouses. II: Ventilation. Journal of Agriculture
Engineering Research, 5: 36-41.

Mistriotis, A., Bot, G.P.A., Picuno, P., Scarascia Mugnozza, G., 1997. Analysis of the efficiency of greenhouse ventilation using computational fluid dynamics. Agricultural and Forest Meteorology, 85 (3-4): 217-228.

Morris, L.G., Neale, F.E., 1954. The infrared carbon dioxide gas analyzer and its use in glass house research. National Institute of Agricultural Engineering, Silsoe, Tech. Memo. 99, p.13.

Nebbali, R., Roy, J.C., Boulard, T., 2012. Dynamic simulation of the distributed radiative and convective climate within a cropped greenhouse. Renewable Energy, 43: 0960-1481.

Nederhoff, E.M., van de Vooren, J., Udink ten Cate, A.J., 1985. A practical tracer gas method to determine ventilation in greenhouses. Journal of Agricultural Engineering Research. 31 (4): 309-319.

Norton, T., Sun, DW., Grant, J., Fallon, R., Dodd, V., 2002. Applications of computational fluid dynamics (CFD) in the modelling and design of ventilation systems in the agricultural industry: A review, Bioresource Technology, 98(12): 2386-2414.

Okada, M., Takakura, T. 1973. Guide and data for greenhouse air conditioning. 3. heat loss due to air infiltration of heated greenhouse. Journal of Agricultural Meteorology, 28 (4): 223-230.

Okushima, L., Sase, S., Nara, M., 1989. A support system for natural ventilation design of greenhouse based on computational aerodynamics. Acta Horticulturae, 248: 129-136.

Papadakis, G., Mermier, M., Meneses, J.F., Boulard, T., 1994. Measurement and analysis of air Exchange rates in a greenhouse with continuous roof and side openings. Journal of Agriculture Engineering Research, 63: 219228.

Patankar, S.V., 1980. Numerical heat transfer and fluid flow. Hemisphere, New York.

Reichrath, S., Davies, T.W., 2002. Computational fluid dynamics simulations and validation of the pressure distribution on the roof of a commercial multi-span Venlo-type glasshouse. Journal of Wind Engineering and Industrial Aerodynamics, 90: 139-149.

Sase, S., Takakura, T., Nara, M., 1984. Wind tunnel testing on air flow and temperature distribution of a naturally ventilated greenhouse. Acta Horticulturae, 148, 329-336.

Sevila, F., Feuilloley, P., Mekikdijan, C., 1992. Natural ventilation of greenhouses on Mediterranean areas. XI CIGR World Congress and Agency 92 Conference on Agricultural Engineering, Uppsala, Sweden, 1-4 June.

Von Zabeltitz, C., 2011. Integrated greenhouse systems for mild winter climates: climatic conditions, design, construction, maintenance and climate control. SpringerVerlag, Berlin 